\title{
Regional economic indicators
}

Sebnem Oguz and Jonathan Knigh
Office for National Statistics

\section{A focus on regional gross value added using shift- share analysis}

\section{Focus on differences in regional economic growth (NUTS1 regions)}

This quarter, the regional economic variations in economic growth rates across NUTS1 regions between 1995 and 2007 by using the shift-share method. The technique is based on the assumption that local economic growth is explained by the combined effect of three components: national growth, industry mix or structural effect, and local competitiveness. Thus, one can apply shift-share to determine how much each component contributes to local economic growth. The regular part of the article then gives an overview of the economic activity of UK regions in terms of their GVA, GVA per head and labour productivity. This is followed by a presentation of headline indicators of regional welfare, other drivers of regional productivity and regional labour market statistics. The indicators cover the nine Government Office Regions of England and the devolved administrations of Northern Ireland, Scotland and Wales. These 12 areas comprise level 1 of the European Nomenclature of Units for Territorial Statistics (NUTS level 1) for the UK. The term 'region' is used to describe this level of geography for convenience in the rest of this article. revious Regional Economic Indicators
(REI) articles have shown significant
and persistent differences in economic performance between and within the UK regions and identified some of the factors (such as productivity) that might account for such differences. The focus section of this article attempts to shed further light on different regional economic performances by investigating the underlying forces of economic growth in 12 NUTS1 regions between 1995 and 2007.

Table 1 shows change in nominal Gross Value Added (GVA) for 12 NUTS1 regions between 1995 and 2007. Total GVA in the UK grew by 90 per cent between 1995 and 2007. Total GVA growth in the regions varied from 65.2 per cent in Wales to 117.5 per cent in London over the same period.

One way to determine why GVA growth rates among regions differed widely during this time period is to use shift-share analysis. The shift-share is a popular technique in regional analysis that examines economic change in a region by splitting the growth of its GVA into three additive components: the reference area such as the national economy effect, the structural effect and regional competitiveness. By applying shift-share analysis to GVA growth in a region one can determine how much of the regional GVA growth may be attributed to the unique local factors and how much of it is due to the national business cycle and the national performance of specific industries.
Table 2 presents a shift-share decomposition of the change in GVA for NUTS 1 regions between 1995 and 2007. It shows that in every region the National Share factor dominated the growth in GVA over this period. This implies that the largest contribution to regional GVA was made by national economic growth over this period. If the GVA in all the regions had grown at the same rate as the national GVA during this period, their GVA would have increased by 90 per cent. However, as shown in Table 1, growth rates actually varied significantly among regions. These differences can be explained by the Industry Mix (IM) and Regional Shift (RS) components of the growth.

Comparing the IM components by region, Table 2 shows that London had the most favourable industry mix, followed by the South East between 1995 and 2007 . In these regions, the industrial structure of the region had a positive effect on the GVA growth. For example, in London, 20 percentage points of the overall GVA growth (117.5 per cent) is explained in shift-share analysis by the region's industry mix. In other regions, negative IM factors imply that the industry mix had a negative effect on regional GVA growth relative to the UK overall. East Midlands and Wales had the least favourable industry mix over this period.

The Regional Shift component, which indicates overall local competitiveness, was positive in half of the regions. The RS factor was highest in Northern Ireland, which more than offset its disadvantage 
Table 1

\section{Change in workplace-based gross value added at current basic prices between 1995 and 2007: by NUTS1 region}

\begin{tabular}{lr} 
& Per cent \\
\hline North East & 66.9 \\
North West & 72.5 \\
Yorkshire and The Humber & 77.3 \\
East Midlands & 84.8 \\
West Midlands & 69.5 \\
East of England & 97.3 \\
London & 117.5 \\
South East & 102.5 \\
South West & 93.8 \\
Wales & 65.2 \\
Scotland & 77.3 \\
Northern Ireland & 93.3 \\
&
\end{tabular}

Source: Regional Accounts, Office for National Statistics

Table 2

Shift-share decomposition of the change in workplace-based gross value added at current basic prices between 1995 and 2007: by NUTS1 region

\begin{tabular}{lrrrr}
\hline & $\begin{array}{r}\text { National } \\
\text { Share (NS) }\end{array}$ & $\begin{array}{r}\text { Industry } \\
\text { Mix (IM) }\end{array}$ & $\begin{array}{r}\text { Regional } \\
\text { Shift (RS) }\end{array}$ & $\begin{array}{r}\text { Total } \\
\text { change } \\
\text { (per cent) }\end{array}$ \\
\hline North East & 89.8 & -8.5 & -14.4 & 66.9 \\
North West & 89.8 & -6.0 & -11.3 & 72.5 \\
Yorkshire and The Humber & 89.8 & -7.0 & -5.5 & 77.3 \\
East Midlands & 89.8 & -12.0 & 7.0 & 84.8 \\
West Midlands & 89.8 & -8.5 & -11.9 & 69.5 \\
East of England & 89.8 & -2.0 & 9.5 & 97.3 \\
London & 89.8 & 20.0 & 7.7 & 117.5 \\
South East & 89.8 & 4.6 & 8.1 & 102.5 \\
South West & 89.8 & -0.9 & 4.9 & 93.8 \\
Wales & 89.8 & -10.9 & -13.7 & 65.2 \\
Scotland & 89.8 & -4.4 & -8.2 & 77.3 \\
Northern Ireland & 89.8 & -9.4 & 12.9 & 93.3 \\
\hline
\end{tabular}

Source: Regional Accounts, Office for National Statistics in industrial structure ensuring its overall economic growth was above the UK average over the 1995 to 2007 period. Similarly, in the South West and the East of England the positive impact of factors specific to the region were more important in terms of overall growth than the negative impacts of their industrial structure. The East Midlands also had a positive regional factor but this could not fully compensate for the negative effect of the industrial structure on GVA growth.

In the South East the regional shift had a more positive impact on the region's economic growth than its industrial structure, whereas in London the industrial structure played a more prominent role than its local competitive advantages in its economic growth. In other regions, both industrial structure and region specific factors had a negative impact on the relative economic growth.

In addition to overall growth, the analysis involved in calculating shift-share can be used to examine how individual industries have fared in the regions. This helps to shed further light on regional differences in the local competitiveness captured by the RS component.

Table 3 presents the GVA growth for each industry by NUTS 1 region between 1995 and 2007. Where a region's growth rate for an industry is higher than the UK growth rate for the same industry then this means that the region has a positive RS component for that industry. A positive RS component for an industry can be considered as

Table 3

Change in workplace-based gross value added at current basic prices between 1995 and 2007: by NUTS1 region and by industry

Per cent



Source: Regional Accounts, Office for National Statistics 


\section{Box 1}

\section{Shift-share}

Shift-share analysis is a sectoral decomposition procedure widely used in regional analysis. Shift-share analysis is a method which examines growth (or decline) rates of a variable such as GVA or employment in a region by splitting it into three additive components:

- a growth effect with respect to a reference area, which in regional applications is commonly the national economy (National Share (NS)). It indicates the regional growth that would occur if GVA in all industries within a region grew at the same rate as the growth rate of the national economy overall during the period of analysis. This component describes the change that would be expected due to the fact that a region is part of a dynamic national economy

- a structural effect (Industry Mix (IM)) which is measured on the basis of the deviation of each industry's national growth rate from the aggregate growth rate of the economy overall. It is the component of growth that is due to regional specialisation in industries. Thus, a local area, with an aboveaverage share of output from the nation's high growth industries would have grown faster (indicated by a positive IM factor) than a local area with a high share of output from low-growth industries (indicated by a negative IM factor)

- a competitive effect (Regional Shift (RS)) which compares a local area's growth rate in an industry sector with the growth rate for that same sector at the national level. The $\mathrm{RS}$ is perhaps the most important component. It highlights a local area's economic strengths by identifying its competitive industries. A competitive industry is defined as one that outperforms its counterpart at the national level (indicated by a positive factor). Regions that have positive (negative) regional shift effects have local advantages (disadvantages) for particular activities that affect the performance of particular industries. The advantages could be due to local firms having superior technology, management or market access, higher local labour productivity compared to other regions and/or lower wages. The RS factor does not tell what these advantages or disadvantages are. However, by looking at this factor it can be determined which industries are performing particularly well in the region

The three components sum to the total shift, which is the actual growth or decline in a region's GVA.

It should be born in mind that the shift-share technique is only a descriptive tool and it does not seek to explain the factors that influence the overall changes in local economies. Additionally, shift-share analysis is a 'snapshot' between two particular time periods and is on occasions sensitive to the time period chosen. However, the time period in this article covers a period of economic growth and sensitivity checks did not show significantly different results when the beginning and the end of time periods were changed.

Overall, shift-share analysis offers a simple, straightforward approach to separating out national and industrial contributions to GVA from local growth effects. The ability to separate local growth factors from national growth factors is an important aspect of understanding local economies. In particular, when used in combination with other analysis the technique offers a valuable tool to better understand a region's economic potential an indication of a region's competitive advantage for that industry. In general the more industries in which a region has a competitive advantage the more likely the region is to have a positive RS component overall (as shown in Table 2).

Table 3 highlights that each region has its own particular competitive advantage. For example, in the East Midlands the Transport, Storage and Communication sector outperformed its regional counterparts whereas London was the most advantageous region for the Financial Intermediation sector between 1995 and 2007. The table also shows that in the East of England, South West, London and East Midlands the advantages indicated by the overall positive RS factor were spread across almost every sector. The high RS component in Northern Ireland, meanwhile, was dominated by the Real Estate, Renting and Business Activities, Construction, Wholesale and Retail Trade and Manufacturing industries all of which also grew faster than their counterparts in other regions between 1995 and 2007.

Overall, the shift-share analysis shows that while the national economic picture is the most important determinant of regional economic output there still exists significant variation in output across the regions.

This variation can be explained in terms of industry mix and regional competitiveness. In London and the South East both these factors made a positive contribution to GVA growth over the 1995 to 2007 period. In the North East, North West, Yorkshire and The Humber, West Midlands, Wales and Scotland, by contrast, both these factors were negative over the same period.

\section{Regional overview}

Key figures on a regional basis indicate that:

- in 2008 London was the region with the highest productivity, in terms of GVA per hour worked, at 33 percentage points above the UK average and diverged further from it while Northern Ireland had the lowest productivity, at 19 percentage points below the UK average

- South East and East of England were the only other regions with a productivity performance above the UK average ( 4 and 0.7 percentage points respectively) in 2008

- the total value of goods exports decreased in all the regions except in Scotland (up by 4 per cent) between March 2009 and March 2010 , but there were significant differences among regions. Northern Ireland had the largest percentage decline in the value of goods exports (down by 18 per cent)

- the South East had the highest employment rate in the first quarter of 2010, at 76.6 per cent; Northern Ireland had the lowest rate, at 67.9 per cent, compared with the UK employment rate of 72.0 per cent

\section{Headline indicators}

In order to gain an overview of the economic performance of UK regions, this article discusses a selection of economic indicators. Currently, the most widely used indicator of regional economic performance is Gross Value Added (GVA) per head. Policymakers frequently use GVA per head as a headline indicator of regional 
Table 4

Workplace-based gross value added and gross value added per head at current basic prices: by NUTS1 region

\begin{tabular}{|c|c|c|c|c|c|c|c|c|c|c|c|c|c|}
\hline & $\mathrm{UK}^{1}$ & $\begin{array}{r}\text { North } \\
\text { East }\end{array}$ & $\begin{array}{r}\text { North } \\
\text { West }\end{array}$ & $\begin{array}{l}\text { Yorkshire } \\
\text { and The } \\
\text { Humber }\end{array}$ & $\begin{array}{r}\text { East } \\
\text { Midlands }\end{array}$ & $\begin{array}{r}\text { West } \\
\text { Midlands }\end{array}$ & $\begin{array}{l}\text { East of } \\
\text { England }\end{array}$ & London & $\begin{array}{r}\text { South } \\
\text { East }\end{array}$ & $\begin{array}{r}\text { South } \\
\text { West }\end{array}$ & Wales & Scotland & $\begin{array}{r}\text { Northern } \\
\text { Ireland } \\
\end{array}$ \\
\hline \multicolumn{14}{|l|}{ GVA (f million) } \\
\hline 1998 & 769,500 & 26,600 & 78,500 & 58,000 & 49,900 & 63,200 & 66,700 & 146,800 & 109,200 & 58,900 & 29,700 & 64,600 & 17,400 \\
\hline $2008^{2}$ & $1,259,600$ & 40,700 & 119,000 & 88,500 & 80,100 & 94,700 & 111,700 & 266,800 & 182,100 & 98,500 & 45,400 & 103,400 & 28,700 \\
\hline $\begin{array}{l}\text { Average annual percentage } \\
\text { growth } 1998-2008^{2}\end{array}$ & 5.1 & 4.3 & 4.2 & 4.3 & 4.8 & 4.1 & 5.3 & 6.2 & 5.2 & 5.3 & 4.3 & 4.8 & 5.1 \\
\hline \multicolumn{14}{|l|}{ GVA per head (f) } \\
\hline 1998 & 13,200 & 10,400 & 11,600 & 11,700 & 12,100 & 12,000 & 12,600 & 20,800 & 13,800 & 12,100 & 10,200 & 12,700 & 10,400 \\
\hline $2008^{2}$ & 20,500 & 15,800 & 17,300 & 17,000 & 18,100 & 17,500 & 19,500 & 35,000 & 21,700 & 18,900 & 15,200 & 20,000 & 16,200 \\
\hline $\begin{array}{l}\text { Average annual percentage } \\
\text { growth } 1998-2008^{2}\end{array}$ & 4.5 & 4.3 & 4.1 & 3.8 & 4.1 & 3.8 & 4.5 & 5.3 & 4.6 & 4.6 & 4.1 & 4.6 & 4.5 \\
\hline
\end{tabular}

\section{Notes:}

1 UK less Extra-regio and statistical discrepancy.

2 Provisional.

productivity and of regional incomes when comparing and benchmarking regions that differ in geographical size, economic output and population. However, as Dunnell (2009) has explained, productivity and income are very different concepts.

GVA per head is calculated as the simple ratio of the economic activity in a region divided by the number of people living in a region, while productivity is defined as the ratio of GVA divided by the labour input (jobs or hours worked) used to create it. GVA per head does not take account of:

- people commuting in and out of regions to work

- regional differences in the percentages of residents who are not directly contributing to GVA, such as young people or pensioners, and

- different labour market structures across regions, such as full- and parttime working arrangements

Therefore, GVA per hour worked or GVA per filled job are more appropriate productivity indicators. It needs to be noted that these indicators also depend on pricing thus productivity can fall/rise with decreasing/increasing prices. As regional price deflators do not yet exist, GVA estimates used in productivity figures are in nominal, not real terms, therefore it is not possible to isolate volume changes from price changes.

Similarly, Gross Disposable Household Income (GDHI) per head is a better measure of regional incomes than GVA per head. For example, due to commuting, residents might derive their incomes from economic activity in another region, which is not captured by GVA per head of their region. They may also have sources of income which are unrelated to current work, such as pensions and investment incomes. GDHI, therefore, is one of the determinants of the welfare of the people in the region.

\section{Regional performance}

GVA is a good measure of the economic output of a region. In December 2009, ONS published GVA estimates for 2008 and revised estimates for previous years. Table 4 shows the regional economic performance in terms of workplace-based GVA and GVA per head and their respective average annual growth over the period 1998 to 2008. Although GVA per head is not a good indicator of regional productivity or income, it does take account of variations in geographical size among UK regions and therefore allows better comparisons than using GVA in total.

The estimates show that London had the highest GVA ( $£ 266.8$ billion) and GVA

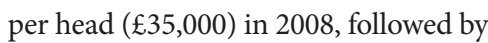
the South East ( $£ 182.1$ billion and $£ 21,700$, respectively). London's GVA per head was 71 per cent above the average for the UK, while that of South East was 6 per cent above the average. The North West generated the third highest GVA ( $£ 119$ billion), but was eighth in terms of its GVA per head $(\mathfrak{1} 17,300)$. Northern Ireland had the lowest GVA in 2008, while Wales had the lowest GVA per head ( 26 per cent below the UK average).

In terms of average annual percentage growth of nominal GVA between 1998 and 2008, London, East of England, South West, South East and Northern Ireland had the highest GVA growth. Average annual percentage growth of GVA in these regions was equal to or above the UK growth. The lowest growth occurred in West Midlands and North West. Average annual percentage growth of GVA per head between 1998 and 2008 was higher than the UK average in
London, Scotland, South East, South West and Northern Ireland, while West Midlands and Yorkshire and The Humber grew slowest over the same period.

\section{Labour productivity}

To compare regions in terms of productivity, GVA per hour worked is the preferred indicator. At lower levels of geography, 'hours worked' estimates are not yet available and GVA per filled job should be used. These two measures of productivity divide GVA by the labour input, namely hours worked in all jobs or the number of jobs used to create it.

GVA per hour worked and GVA per filled job take account of commuting effects and different age profiles, and the former also accounts for variations in labour market structures, such as full- and parttime working arrangements and job share availability.

Productivity estimates for 2008 and revised estimates for previous years were published in February 2010. These estimates make use of the GVA figures presented in Table 4, and updated 'filled jobs' and 'hours worked' estimates.

It should be noted that the productivity figures presented here use unsmoothed GVA as their output measure as opposed to headline GVA, which is calculated as a five-year moving average. The unsmoothed measure is used to ensure consistency with the labour input data (Dey-Chowdhury et al 2008), but raises some concerns about increased volatility of productivity estimates compared to those based on headline GVA. The question of whether to smooth productivity figures after dividing unsmoothed GVA by labour data, and presenting these as headline estimates, is one which will be addressed by ONS in the coming months. 
Figure 1

Comparison of regional economic indicators: by NUTS1 region, $2008^{1}$

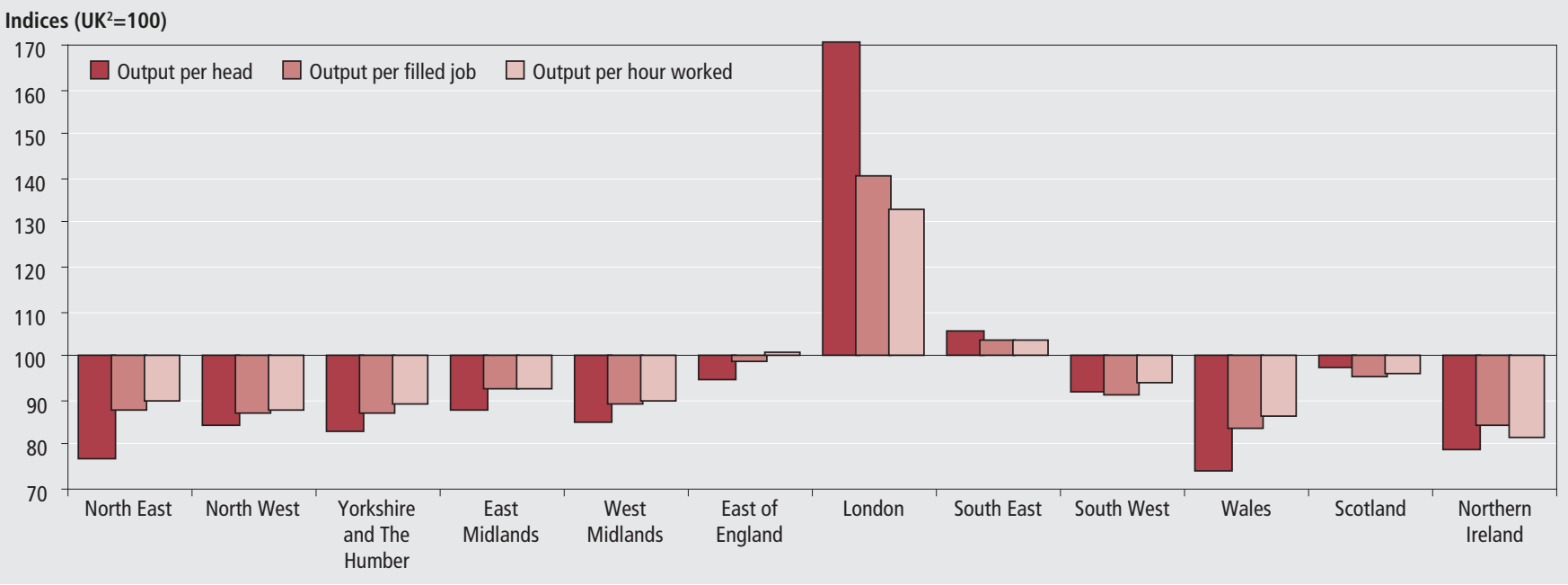

Notes:

Source: Office for National Statistics

1 Provisional.

2 UK less Extra-regio statistical discrepancy.

Figure 2

GVA per hour worked: by NUTS1 region

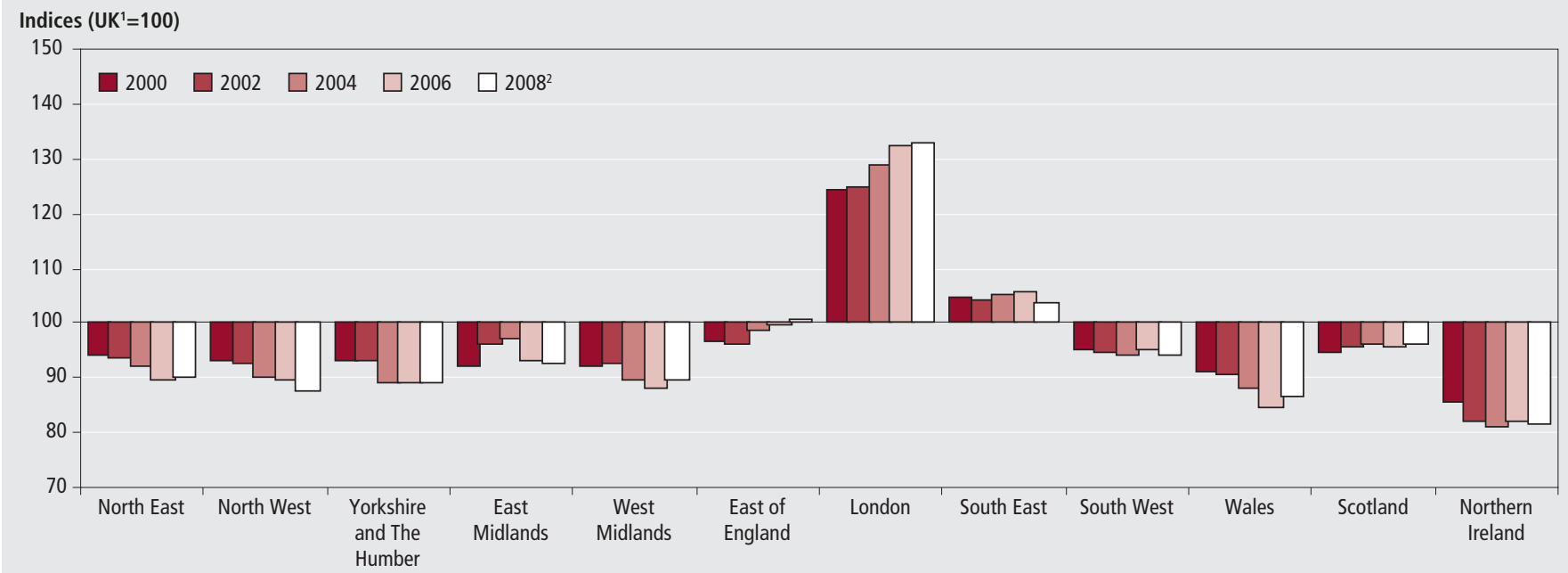

Notes:

Source: Office for National Statistics

1 UK less Extra-regio and statistical discrepancy.

2 Provisional.

Figure 1 shows that in 2008 GVA per filled job and GVA per hour worked exhibited smaller differences from the UK average than the catch-all indicator GVA per head. This is mainly due to commuting patterns. London, for example, has a very high GVA per head, mainly due to incoming workers generating a high GVA, which is then divided by a much lower resident population. Productivity indicators, on the other hand, divide regional GVA by the jobs or hours worked used to create it.

Figure 2 shows the regional GVA per hour worked productivity index on a time series basis from 2000 to 2008. In 2008, London, the South East and the East of England were the only three regions with a productivity performance above the UK average. The East of England saw the strongest improvement in its relative performance from below the UK average in 2000 to above average in 2008. London continued to improve its relative performance, therefore diverging further from the UK average. Relative productivity in the South East weakened slightly in 2008, but it remained above the UK average over the period. Northern Ireland and Wales had the lowest relative productivity compared to the UK average in 2008. Relative productivity in most regions diverged from the UK average between 2000 and 2008. The strongest divergence below the UK average productivity over this period was experienced in the North West, Wales and Northern Ireland. This indicates that these regions' productivity grew by less than the UK average, therefore widening the productivity gap between regions.

\section{Income of residents}

Figure 3 presents indices of GDHI per head for 1996, 2000, 2004 and 2008, showing movements in regional household income relative to the UK average over time. It is evident that the GDHI per head is above the UK average only in the regions of the 'Greater South East'. Of these regions, London has consistently had the highest GDHI per head since 1996 and is diverging from the national average. The South East and East of England, on the other hand, are getting closer to the national average as they experienced relatively lower growth 


\section{Figure 3}

\section{Headline gross disposable household income per head: by NUTS1 region}



\section{Notes:}

Source: Office for National Statistics

1 UK less Extra-regio.

2 Provisional.

Figure 4

Gross median weekly pay of all full-time employees: ${ }^{1}$ by NUTS1 region, April 2009

f

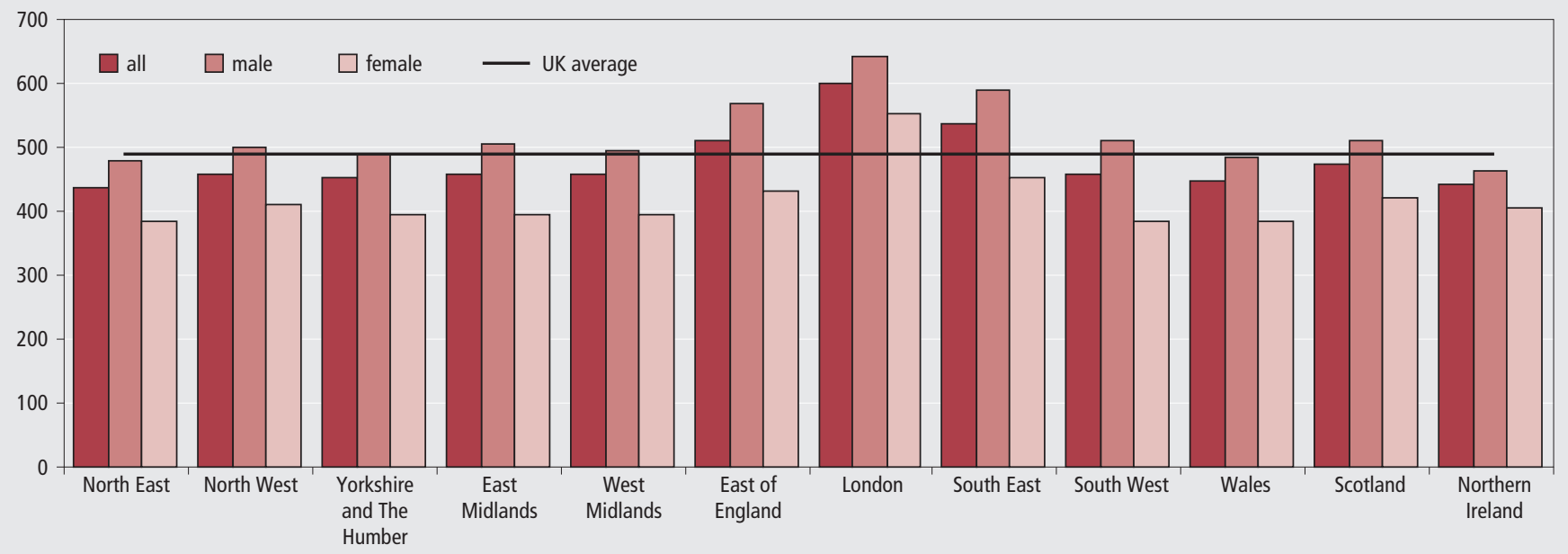

Note:

Source: Annual Survey of Hours and Earnings, Office for National Statisticss

1 Residents of the respective region.

in household income compared to the national average between 2000 and 2008 . Most of the regions with relatively lower household income diverged further from the national average while improvements against national average are evident in the devolved administrations between 2000 and 2008.

Gross median weekly earnings represent another indicator of regional welfare.

Figure 4 shows the gross median weekly pay for all full-time employees, split into female and male full-time employees, living in each region in April 2009.

As in previous years, London was the region with the highest gross median weekly pay, at $£ 598.60$, followed by the South East, at $£ 536.60$ and the East of
England, at $£ 509.40$. These were the only regions above the UK average of $£ 488$.70. North East ( $£ 438.80)$, Northern Ireland ( $£ 440.80$ ), and Wales ( $£ 449.90)$ recorded the lowest earnings in April 2009.

Females across the UK regions received lower pay than males. In Northern Ireland, the discrepancy was smallest, while it was largest in the South East and East of England. In terms of annual average percentage growth over the four years to 2009, pay for females outperformed that for males except in the South West. The highest annual average growth rate for male pay was observed in the North East while Scotland had the highest annual average growth rate for male pay between 2005 and 2009.

\section{Drivers of productivity}

HM Treasury and the Department for Business, Innovation and Skills (BIS) have identified five key drivers of productivity - investment, innovation, enterprise, competition and skills - that can help explain differences in productivity across regions.

Alongside these five key drivers, other factors, such as connectivity, industrial structure and region-specific assets can have a strong influence on regional productivity performance.

This article uses expenditure on Research and Development (R\&D) by businesses as a measure of innovation; the numbers of business births and deaths and survival rates as an indicator for enterprise; UK 
regional trade in goods serves as a measure of competition; and the qualifications of the current working-age population and those of young people, who represent the future workforce, to provide an indicator for the skills driver.

\section{Innovation}

Innovation is a necessary, although not sufficient, condition for economic success and is therefore recognised as an important driver of productivity. Innovation comprises, among others, the development of new technologies that increase efficiency and the introduction of new, more valuable goods and services. It also includes intangibles such as new methods of working and improvements to services.

$\mathrm{R} \& \mathrm{D}$ represents one of the determinants to the innovation process and is defined by the Organisation for Economic Cooperation and Development (OECD) in its Frascati Manual, which proposes a standard practice for surveys on $\mathrm{R} \& \mathrm{D}$, as 'creative work undertaken on a systematic basis in order to increase the stock of knowledge, including knowledge of man, culture and society, and the use of this stock of knowledge to create new applications'. The OECD definition of R\&D covers the following:

- basic research - experimental and theoretical work to obtain new knowledge of the underlying foundation of phenomena and observable facts, without any particular application or use in view

- applied research - work undertaken to acquire new knowledge, which is directed primarily towards a specific practical aim, and

- experimental development - systematic work, drawing on existing knowledge, which is directed at producing new materials, products or devices, installing new processes, systems and services, or at improving substantially those already produced or installed

The OECD definition excludes education, training and any other related scientific, technological, industrial, administrative or supporting activities. However, innovation depends on a wider set of inputs than R\&D, including skills training, design, software and organisational investment by firms. HM Treasury Economics Working Paper No. 1 quantifies these broader knowledge economy inputs at UK level; more work is needed before these factors can be measured effectively at regional level.

Figure 5 presents statistics on Business Enterprise Research and Development (BERD), which are consistent with internationally agreed standards. Figures for 2008 published on 11 December 2009 show business expenditure on $R \& D$ as a percentage of workplace-based GVA in 2000, 2002, 2004, 2006 and 2008. This is a measure commonly used in regional comparisons as it takes account of the size of regional economies. The figure shows that, since 2000, the East of England has been the region with by far the highest percentage of R\&D expenditure in terms of GVA, with 3.7 per cent in 2008. The North West and the South East regions had the second highest percentage (1.9 per cent) which has, however, been declining in the South East since 2000. These three regions together also accounted for 62 per cent of the total expenditure on R\&D in 2008.

London had the lowest $\mathrm{R} \& \mathrm{D}$ expenditure as a share of its regional GVA in 2008 (0.4 per cent). Yorkshire and the Humber, Wales and Scotland had the second lowest shares in the UK in 2008 , at 0.5 per cent each. London's very low share of expenditure on R\&D does not necessarily suggest low levels of innovation but may be due to it having a large concentration of service industries, which may be less $R \& D$ intensive (within the OECD definition) if, for example, they rely heavily on human capital. It may also reflect the choice businesses make over locating their R\&D activities.

Approximately three-quarters of the $\mathrm{R} \& \mathrm{D}$ expenditure in the UK was made in the manufacturing sector in 2008. Figure 6 shows that in most regions except in the Greater South East the share of the R\&D expenditure on manufacturing was over 80 per cent of their respective expenditure. The figure also shows that East of England accounted for 26 per cent of the total R\&D expenditure in the UK in 2008 and had the highest level of $\mathrm{R} \& \mathrm{D}$ expenditure on both manufacturing and services. This may suggest that some London R\&D occurs in the surrounding regions such as Cambridge technology start-ups. .

\section{Enterprise}

Enterprise is another driver of productivity. It is defined as the seizing of new business opportunities by both start-ups and existing

\section{Figure 5}

\section{Business expenditure on R\&D as a percentage of workplace-based GVA: by NUTS1 region}

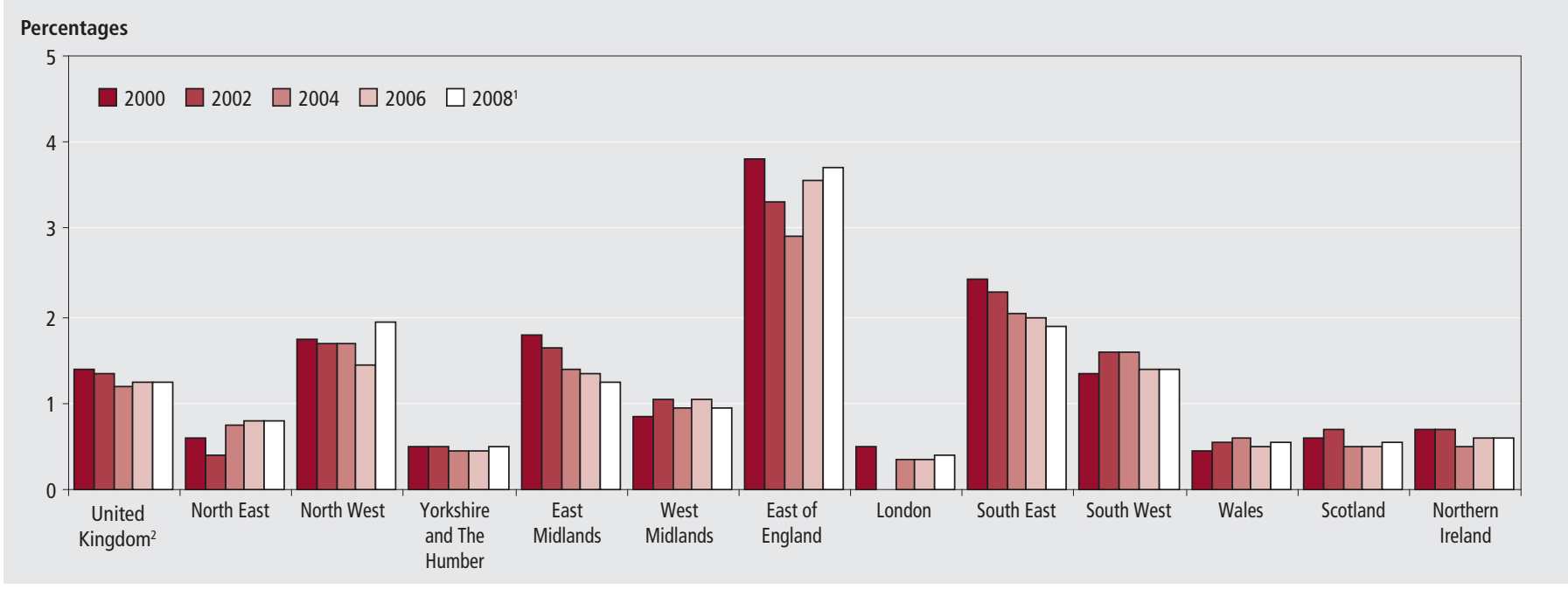

\section{Notes:}

Source: Regional Accounts and Business Enterprise Research \& Development, Office for National Statistics

1 Provisional.

2 UK less Extra-regio and statistical discrepancy. 


\section{Figure 6}

\section{Business expenditure on R\&D by NUTS1 region: broad industry groups, 2008}

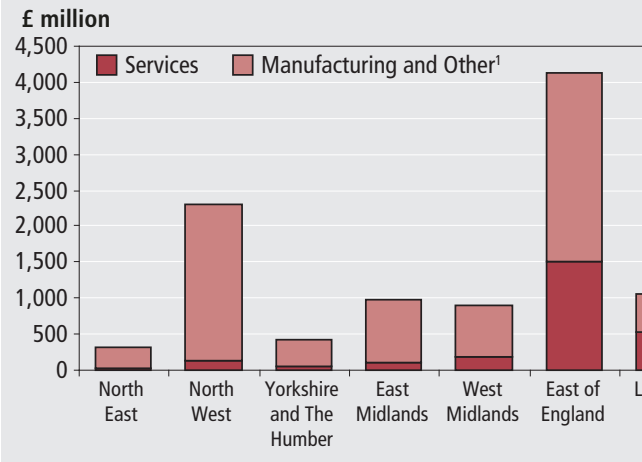

Note:

1 Other includes agriculture, hunting and forestry, fishing, extractive industries, electricity, gas and water supply and construction. The expenditure on other industries across the UK was less than 2 per cent of the total expenditure.

\section{Figure 7}

\section{Enterprise births, deaths ${ }^{1}$ and net change as a percentage of enterprise stock: by NUTS1 region, 2008}

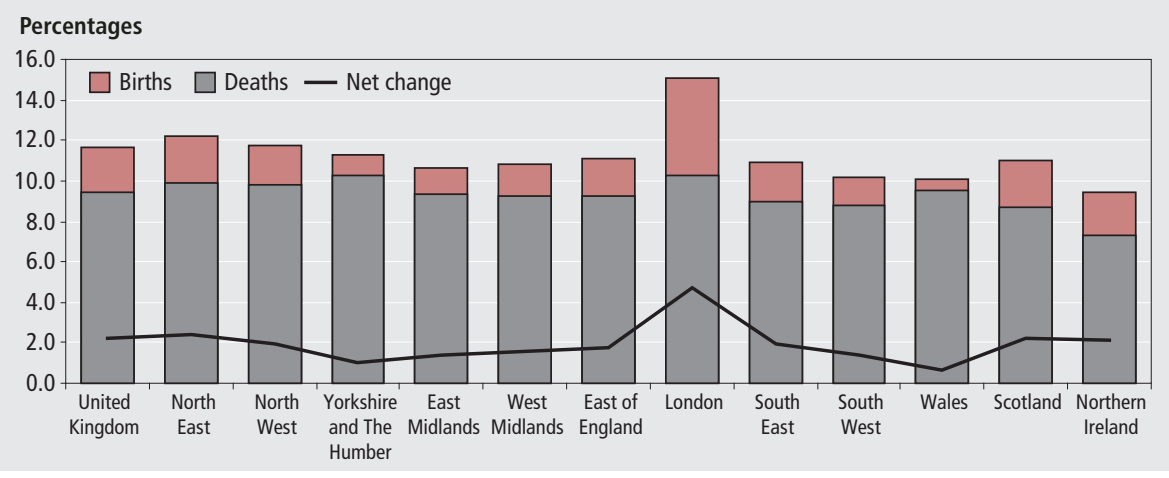

Note:

Source: Business Demography, Office for National Statistics

1 Provisional.

Figure 8


Source: Business Demography, Office for National Statistics

firms. New enterprises can bring innovative processes and technologies to the market, forcing existing ones to improve their productivity in order to remain competitive. A relatively large proportion of enterprises joining and leaving the stock can be seen as desirable, as new enterprises entering the market are considered to bring innovative processes and technologies that drive up productivity and force unproductive enterprises to leave the market.

The February 2009 edition of this article focused on business demography in UK regions, using the newly published ONS series of enterprise births and deaths, which includes enterprises registered for VAT and also those registered for pay-as-you-earn (PAYE). It needs to be noted that enterprise statistics relate to the place of registration of the enterprise, even though the enterprise may consist of more than one local unit, possibly in different regions.

Figure 7 shows the number of births and deaths of enterprises as a proportion of the active enterprise stock in 2008. The difference between the two represents the net change, which is calculated as a proportion of total stock. In 2008, across all regions, the net changes were positive due to higher proportions of enterprises joining the stock than leaving it. These proportions were largest in London (4.7 per cent), followed by the North East (2.4 per cent). The lowest rate of net change was in Wales (0.6 per cent).

These rates were mainly driven by small enterprises with fewer than 5 employees which is approximately 80 percent of the total enterprise stock

As well as analysing births and deaths of enterprises, it is useful to look at how long these enterprises survive. The Business Demography series contains data showing the number of years survived by enterprises born in the years 2003 to 2005 .

Figure 8 shows the proportion of enterprises born in 2003, 2004 and 2005 that survived for at least three years each. It shows that, overall in the UK, survival rates increased from 63.6 per cent of enterprises born in 2003 to 65.3 per cent of those born in 2004 and went back down slightly to 64.7 per cent of those born in 2005.

Patterns were similar across regions. In most regions enterprises born in 2004 had the highest three year survival rates compared to 2003 and 2005. Northern Ireland had the highest three year survival rates which were above the UK average for the enterprises born in all three years while London stands out as the region with the lowest rates. Figure 7 has shown that London had the highest percentage of births and deaths of enterprises and that survival rates were relatively low. They could be an indication of London's ability to exploit short-term business opportunities. At the same time, it may suggest that many of the new enterprises born will not provide longterm growth and employment.

\section{Competition}

Vigorous competition enhances productivity by creating incentives to 
Table 5

UK regional trade in goods - statistical value of exports: ${ }^{1}$ by NUTS1 region

f million

\begin{tabular}{|c|c|c|c|c|c|c|c|c|c|c|c|c|c|}
\hline Exports & $\begin{array}{r}\text { United } \\
\text { Kingdom }\end{array}$ & $\begin{array}{r}\text { North } \\
\text { East }\end{array}$ & $\begin{array}{r}\text { North } \\
\text { West }\end{array}$ & $\begin{array}{c}\text { Yorkshire } \\
\text { and The } \\
\text { Humber }\end{array}$ & $\begin{array}{r}\text { East } \\
\text { Midlands }\end{array}$ & $\begin{array}{r}\text { West } \\
\text { Midlands }\end{array}$ & $\begin{array}{l}\text { East of } \\
\text { England }\end{array}$ & London & $\begin{array}{r}\text { South } \\
\text { East }\end{array}$ & $\begin{array}{r}\text { South } \\
\text { West }\end{array}$ & Wales & Scotland & $\begin{array}{r}\text { Northern } \\
\text { Ireland }\end{array}$ \\
\hline \multicolumn{14}{|l|}{ EU Exports } \\
\hline 2008 Q2 & 37,251 & 1,631 & 3,362 & 1,887 & 2,121 & 2,506 & 3,591 & 2,445 & 5,354 & 1,935 & 1,631 & 1,491 & 970 \\
\hline 2008 Q3 & 35,737 & 1,620 & 3,282 & 1,913 & 2,012 & 2,138 & 3,222 & 2,853 & 5,102 & 1,700 & 1,647 & 1,534 & 871 \\
\hline 2008 Q4 & 32,677 & 1,447 & 2,861 & 1,828 & 1,908 & 1,996 & 2,898 & 2,389 & 5,171 & 1,557 & 1,329 & 1,512 & 856 \\
\hline 2009 Q1 & 31,224 & 1,334 & 3,094 & 1,612 & 1,907 & 1,798 & 2,824 & 2,445 & 4,910 & 1,671 & 1,188 & 1,331 & 791 \\
\hline Total to Mar 2009 & 136,888 & 6,032 & 12,600 & 7,240 & 7,949 & 8,438 & 12,535 & 10,131 & 20,537 & 6,864 & 5,796 & 5,868 & 3,488 \\
\hline 2009 Q2 & 29,392 & 1,311 & 2,958 & 1,464 & 1,802 & 1,696 & 2,899 & 2,397 & 4,358 & 1,569 & 1,179 & 1,233 & 763 \\
\hline 2009 Q3 & 30,323 & 1,352 & 2,899 & 1,472 & 1,702 & 1,634 & 2,948 & 2,806 & 4,563 & 1,443 & 1,163 & 1,341 & 717 \\
\hline 2009 Q4 & 32,612 & 1,488 & 2,931 & 1,745 & 1,822 & 1,893 & 3,530 & 2,530 & 4,901 & 1,490 & 1,258 & 1,440 & 769 \\
\hline $2010 \mathrm{Q}^{2}$ & 33,901 & 1,526 & 2,807 & 1,782 & 1,781 & 1,873 & 3,254 & 2,947 & 4,750 & 1,477 & 1,140 & 1,211 & 726 \\
\hline Total to Mar 2010 & 126,228 & 5,676 & 11,596 & 6,464 & 7,107 & 7,096 & 12,631 & 10,680 & 18,573 & 5,979 & 4,741 & 5,225 & 2,975 \\
\hline
\end{tabular}

\begin{tabular}{|c|c|c|c|c|c|c|c|c|c|c|c|c|c|}
\hline \multicolumn{14}{|l|}{ Non-EU exports } \\
\hline 2008 Q2 & 27,803 & 1,335 & 2,862 & 1,712 & 1,941 & 1,989 & 2,509 & 3,660 & 4,993 & 1,178 & 1,074 & 2,066 & 639 \\
\hline 2008 Q3 & 28,265 & 1,357 & 2,936 & 1,707 & 1,914 & 2,142 & 2,267 & 3,577 & 5,173 & 1,373 & 1,312 & 2,103 & 623 \\
\hline 2008 Q4 & 28,181 & 1,112 & 2,807 & 1,522 & 2,089 & 1,900 & 2,252 & 3,749 & 5,430 & 1,306 & 1,298 & 2,224 & 806 \\
\hline 2009 Q1 & 22,909 & 977 & 2,766 & 1,260 & 1,958 & 1,209 & 1,893 & 2,711 & 4,090 & 1,149 & 1,074 & 1,978 & 510 \\
\hline Total to Mar 2009 & 107,158 & 4,781 & 11,370 & 6,200 & 7,901 & 7,241 & 8,921 & 13,697 & 19,686 & 5,006 & 4,758 & 8,370 & 2,578 \\
\hline 2009 Q2 & 24,812 & 881 & 2,540 & 1,263 & 1,995 & 1,504 & 2,001 & 2,934 & 4,722 & 1,164 & 1,241 & 2,337 & 606 \\
\hline 2009 Q3 & 25,051 & 1,014 & 3,383 & 1,365 & 1,751 & 1,588 & 1,954 & 2,883 & 4,654 & 1,078 & 933 & 2,502 & 454 \\
\hline 2009 Q4 & 28,673 & 1,273 & 3,271 & 1,511 & 1,786 & 2,268 & 2,328 & 3,172 & 5,910 & 1,122 & 968 & 2,809 & 525 \\
\hline $2010 Q^{2}$ & 26,265 & 1,014 & 2,721 & 1,364 & 1,701 & 1,914 & 1,985 & 3,934 & 5,114 & 1,697 & 894 & 1,877 & 442 \\
\hline Total to Mar 2010 & 104,801 & 4,181 & 11,916 & 5,503 & 7,233 & 7,274 & 8,268 & 12,922 & 20,401 & 5,062 & 4,035 & 9,525 & 2,027 \\
\hline \multicolumn{14}{|l|}{ Total Exports } \\
\hline 2008 Q2 & 65,054 & 2,966 & 6,224 & 3,598 & 4,061 & 4,495 & 6,100 & 6,106 & 10,347 & 3,113 & 2,706 & 3,556 & 1,608 \\
\hline 2008 Q3 & 64,002 & 2,977 & 6,218 & 3,620 & 3,926 & 4,280 & 5,489 & 6,429 & 10,275 & 3,074 & 2,959 & 3,637 & 1,495 \\
\hline 2008 Q4 & 60,857 & 2,560 & 5,667 & 3,351 & 3,997 & 3,897 & 5,150 & 6,138 & 10,601 & 2,863 & 2,627 & 3,736 & 1,661 \\
\hline 2009 Q1 & 54,133 & 2,311 & 5,860 & 2,872 & 3,865 & 3,007 & 4,717 & 5,155 & 9,000 & 2,820 & 2,262 & 3,309 & 1,302 \\
\hline Total to Mar 2009 & 244,046 & 10,814 & 23,969 & 13,441 & 15,849 & 15,679 & 21,456 & 23,828 & 40,222 & 11,870 & 10,554 & 14,238 & 6,066 \\
\hline 2009 Q2 & 54,204 & 2,191 & 5,498 & 2,727 & 3,797 & 3,200 & 4,901 & 5,331 & 9,081 & 2,733 & 2,420 & 3,570 & 1,368 \\
\hline 2009 Q3 & 55,373 & 2,366 & 6,282 & 2,838 & 3,452 & 3,222 & 4,903 & 5,689 & 9,217 & 2,521 & 2,096 & 3,843 & 1,172 \\
\hline 2009 Q4 & 61,285 & 2,761 & 6,203 & 3,256 & 3,608 & 4,161 & 5,857 & 5,702 & 10,812 & 2,612 & 2,226 & 4,249 & 1,294 \\
\hline $2010 \mathrm{Q1}^{2}$ & 60,166 & 2,540 & 5,529 & 3,146 & 3,482 & 3,787 & 5,239 & 6,881 & 9,865 & 3,174 & 2,034 & 3,088 & 1,168 \\
\hline Total to Mar 2010 & 231,028 & 9,858 & 23,511 & 11,967 & 14,339 & 14,370 & 20,899 & 23,603 & 38,974 & 11,041 & 8,776 & 14,750 & 5,002 \\
\hline
\end{tabular}

Notes:

Source: Office for National Statistics

1 Components may not sum to totals as Regional Trade Statistics includes estimates made for EU trade below the Intrastat threshold which are included in the 'unknown' region and not displayed in this table.

2 Provisional.

innovate and ensure that resources are allocated to the most efficient firms. It also forces existing firms to organise work more effectively through imitations of organisational structures and technology. One indicator of competition is the volume of exports. Even though exports do not represent competition within a region, they still provide an indication of how international regions are in their outlook, and how able they are to face global competition.

HM Revenue \& Customs (HMRC) publishes statistics on regional trade in goods to the EU and non-EU destinations by statistical value. Trade in goods by definition excludes trade in intangibles and services. The statistical value of export trade is calculated as the value of the goods plus the cost of movement to the country's border.
Table 5 presents the latest quarterly estimates up to the end of March 2010. The total value of UK goods exports to all destinations decreased by 5.3 per cent between March 2009 and March 2010. The total value of goods exports also decreased in all the regions except in Scotland (up by 4 per cent), but there were significant differences among regions. Northern Ireland had the largest percentage decline in the value of goods exports (down by 17.5 per cent), followed by Wales (down by 16.8 per cent) and Yorkshire and the Humber (down by 11.0 per cent).

As the European Union (EU) is the main export destination for UK goods, the Table separates exports to EU and non-EU destinations. In the UK as a whole, the value of exports to the EU dropped by 7.8 per cent between March 2009 and March 2010.
With the exception of East of England (up by 0.8 per cent) and London (up by 5.4 per cent), all the regions recorded decreases in the value of goods exports to the EU. Wales reported the highest drop, by 18.2 per cent.

The total value of the UK exports to the rest of the world declined by 2.2 per cent from March 2009 to March 2010, with the highest drop occurring in Northern Ireland (down by 21.4 per cent). North West, West Midlands, South East, South West and Scotland had an increase in the value of their goods exports to the rest of the world.

The number of exporters in the UK for the March 2010 quarter compared with the same quarter last year, decreased by 4.0 per cent to 47,327 . The North West region had the largest decrease of 5.7 per cent to $4,358^{1}$. There were no regions where the number of exporters increased. 


\section{Figure 9}

\section{Value of total export goods as a percentage of workplace-based GVA: by NUTS1 region}

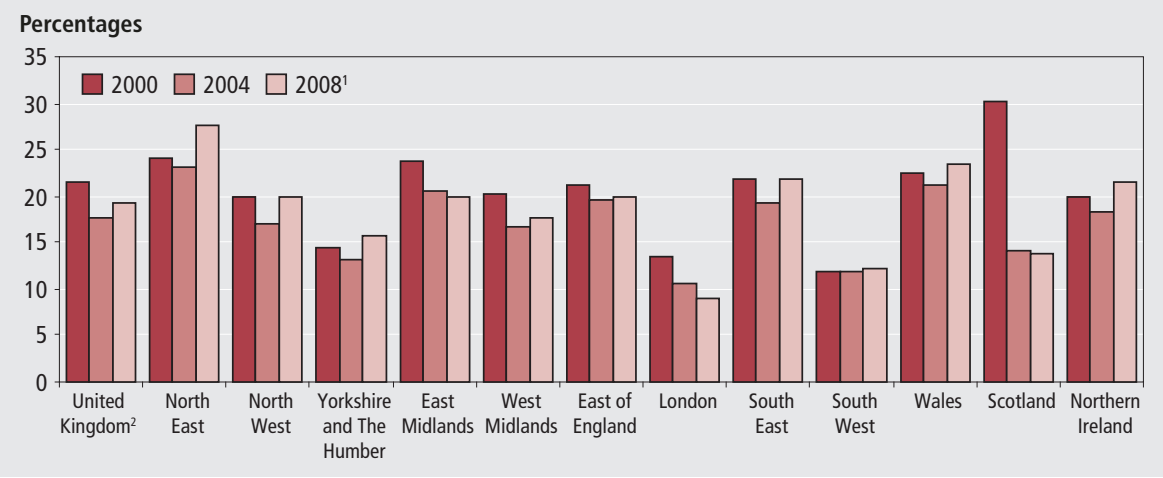

Notes: $\quad$ Source: HM Revenue \& Customs, Regional Trade Statistics and Office for National Statistics 1 Provisional.

2 UK less Extra-regio and statistical discrepancy.

Figure 10

Working-age population with no qualifications: ${ }^{1}$ by NUTS1 region, 2008

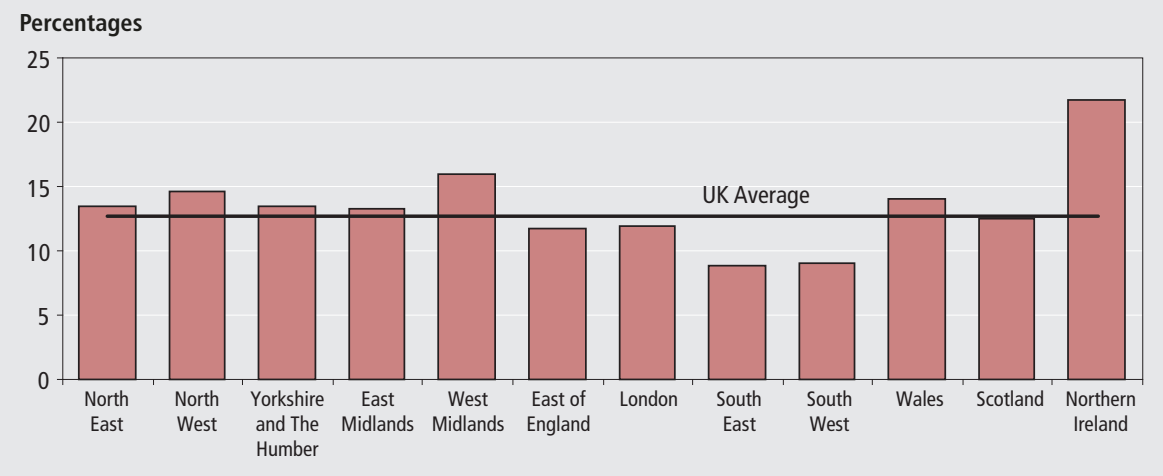

Note:

Source: Labour Force Survey, Office for National Statistics

1 For summary of qualifications and equivalents see

www.statistics.gov.uk/statbase/Product.asp?vlnk=836.

Figure 9 shows the value of exports of goods as a percentage of workplace-based regional GVA in 2000, 2004 and 2008, which takes account of the differing sizes of regional economies. In 2008, the value of goods exports relative to the size of the regional economy was greatest in the North East and lowest in London. It needs to be noted that these figures show exports of goods as a percentage of headline GVA which also includes services and therefore is likely to underestimate the export performance of some regions with a large share of services industries such as London.

In terms of this indicator's change over time, exports relative to GVA were lower in all the regions in 2004 than in 2000, with some recovery in 2008 except in East Midlands, London and Scotland. In Scotland, exports as a percentage of regional GVA dropped significantly between 2000 and 2004, but remained fairly stable over the four years to 2008. The North East had the largest increase in relative export performance, followed by Northern Ireland between 2004 and 2008 .

\section{Skills}

The skills of workers influence productivity as they define the capabilities that the labour force can contribute to the production process. The concept of skills includes attributes of the workforce, such as 'softer' or interpersonal skills, which are difficult to measure or to compare in different situations or over time.

Therefore, qualifications are often used as proxy indicators. By examining the qualifications, such as degree or equivalent, of the current workforce as well as those of young people, who represent the future capabilities of the labour market, a view of how skills are changing over time and their potential impact on productivity can be analysed. However, as characteristics of local economies dictate which labour skills are required, comparability between regions might be difficult. An alternative approach is to compare the percentage of the working-age population that has no recognised qualifications.

Figure 10 shows the proportion of the working-age population that has no qualifications in each region, alongside the UK average, for 2008. Northern Ireland had the highest proportion of the population with no qualifications (9.1 percentage points above the UK average); whereas the South East and the South West had the lowest proportions, 3.8 and 3.7 percentage points below the UK average, respectively.

Above average proportions of workingage people without a qualification do not necessarily mean that regions have the most unqualified workforce. Due to differing regional skill requirements, people with recognised qualifications might migrate into other regions, where demand for their qualifications is high, while those without any recognised qualifications might migrate out of these other regions. Also, if employers have a strong demand for lower skills and a good supply of appropriate workers, a low skill equilibrium is created in a region.

Regional Skills Partnerships (RSPs) are groups brought together by Regional Development Agencies in each region of England in response to the National Skills Strategy. RSPs aim to strengthen regional structures to make skills provision more relevant to the needs of employers and individuals, covering private, public and voluntary sectors of the economy. They also aim to give regions the flexibility to tackle their own individual challenges and priorities.

Table 6 presents the RSP core indicators, which help to monitor the health of regional and local labour markets and progress towards national skills targets such as those documented in the Leitch Report. These core indicators will be supported by local, more specific, indicators identified by individual RSPs. The choice of ' 19 to state pension age' for some of the indicators in Table 6 has been influenced by: the increased emphasis on education and training after the age of 16; the plan to raise the standard school leaving age to 18 ; and alignment with indicators specified in the Local Area Agreements.

In order to assess the future capabilities of the labour force, the percentage of pupils achieving five or more grades $A^{*}$ to $C$ at GCSE level or equivalent in each English region can be used as an indicator ${ }^{2}$. Recent focus on literacy and numeracy has led to a new measure being published, of five or more GCSEs grade $A^{\star}$ to $C$ in subjects 
Table 6

Regional Skills Partnerships core indicators: by NUTS1 region

Percentages

\begin{tabular}{|c|c|c|c|c|c|c|c|c|c|c|c|}
\hline Skills outcome indicators & Time period & $\begin{array}{r}\text { North } \\
\text { East }\end{array}$ & $\begin{array}{r}\text { North } \\
\text { West }\end{array}$ & $\begin{array}{c}\text { Yorkshire } \\
\text { and The } \\
\text { Humber }\end{array}$ & $\begin{array}{r}\text { East } \\
\text { Midlands }\end{array}$ & $\begin{array}{r}\text { West } \\
\text { Midlands }\end{array}$ & $\begin{array}{l}\text { East of } \\
\text { England }\end{array}$ & London & $\begin{array}{r}\text { South } \\
\text { East }\end{array}$ & $\begin{array}{r}\text { South } \\
\text { West }\end{array}$ & England \\
\hline $\begin{array}{l}\text { Percentage of employers with business or } \\
\text { training plan, or budget for training }\end{array}$ & 2007 & 70.6 & 69.2 & 69.6 & 67.9 & 67.5 & 67.3 & 70.0 & 70.6 & 68.4 & 69.1 \\
\hline Percentage of staff with skill gaps & 2007 & 6.3 & 5.3 & 4.8 & 6.8 & 5.4 & 7.8 & 6.7 & 5.8 & 6.2 & 6.1 \\
\hline $\begin{array}{l}\text { Skill shortage vacancies (SSVI) as } \\
\text { percentage of all vacancies }\end{array}$ & 2007 & 18.8 & 17.6 & 20.1 & 20.2 & 15.5 & 19.6 & 26.1 & 22.5 & 20.9 & 20.9 \\
\hline $\begin{array}{l}\text { Percentage of KS4 pupils achieving 5+ } \\
A^{*} \text { to C GCSE (inc Maths and English) }\end{array}$ & $2008 / 09$ & 48.1 & 49.9 & 47.3 & 49.9 & 48.5 & 51.9 & 54.0 & 53.7 & 51.8 & 49.8 \\
\hline $\begin{array}{l}\text { Percentage of } 19 \text { year olds qualified to } \\
\text { Level } 2 \text { or above } 1\end{array}$ & 2008 & 75.9 & 74.3 & 73.2 & 73.1 & 74.9 & 77.0 & 77.0 & 79.6 & 77.0 & 76.7 \\
\hline $\begin{array}{l}\text { Percentage of } 19 \text { year olds qualified to } \\
\text { Level } 3 \text { or above1 }\end{array}$ & 2008 & 43.7 & 46.1 & 44.4 & 46.0 & 46.9 & 52.4 & 51.9 & 56.9 & 51.0 & 49.8 \\
\hline $\begin{array}{l}\text { Percentage of } 19 \text { to state pension age } \\
\text { with Level } 2+\end{array}$ & 2008 & 69.3 & 68.1 & 67.6 & 67.0 & 65.8 & 67.6 & 71.0 & 73.1 & 72.2 & 69.4 \\
\hline $\begin{array}{l}\text { Percentage of } 19 \text { to state pension age } \\
\text { with Level } 3+\end{array}$ & 2008 & 46.9 & 47.1 & 47.1 & 46.3 & 45.2 & 46.5 & 55.0 & 53.7 & 51.7 & 49.5 \\
\hline $\begin{array}{l}\text { Percentage of } 19 \text { to state pension age } \\
\text { with Level } 4+\end{array}$ & 2008 & 25.4 & 27.4 & 26.6 & 27.0 & 26.2 & 27.8 & 40.6 & 33.6 & 30.2 & 30.5 \\
\hline $\begin{array}{l}\text { Percentage of } 19 \text { to state pension age } \\
\text { with no qualifications }\end{array}$ & 2008 & 13.2 & 14.4 & 12.9 & 12.8 & 15.6 & 11.5 & 11.6 & 8.5 & 8.4 & 11.9 \\
\hline $\begin{array}{l}\text { Percentage of working-age population } \\
\text { who undertook job-related training in } \\
\text { last } 13 \text { weeks }\end{array}$ & 2008 & 20.9 & 18.9 & 19.4 & 20.2 & 19.4 & 18.7 & 18.2 & 22.2 & 23.1 & 20.0 \\
\hline $\begin{array}{l}\text { Percentage of } 17 \text { year olds in education } \\
\text { or work-based learning }\end{array}$ & 2008 & 80.0 & 80.0 & 76.0 & 77.0 & 80.0 & 79.0 & 89.0 & 79.0 & 79.0 & 80.0 \\
\hline
\end{tabular}

\section{Note:}

1 Provisional data from DCSF matched datasets.
Source: Office for National Statistics: Labour Force Survey; Department of Business Enterprise and Regulatory Reform; Department for Children, Schools and Families; Department for Innovation Universities and Skills; National Employers Skills Survey 2007.

Figure 11

Pupils achieving five or more grades $A$ * to $C$ at GCSE level or equivalent in (i) all subjects and (ii) subjects including English and Mathematics: by NUTS1 region, 2008/091

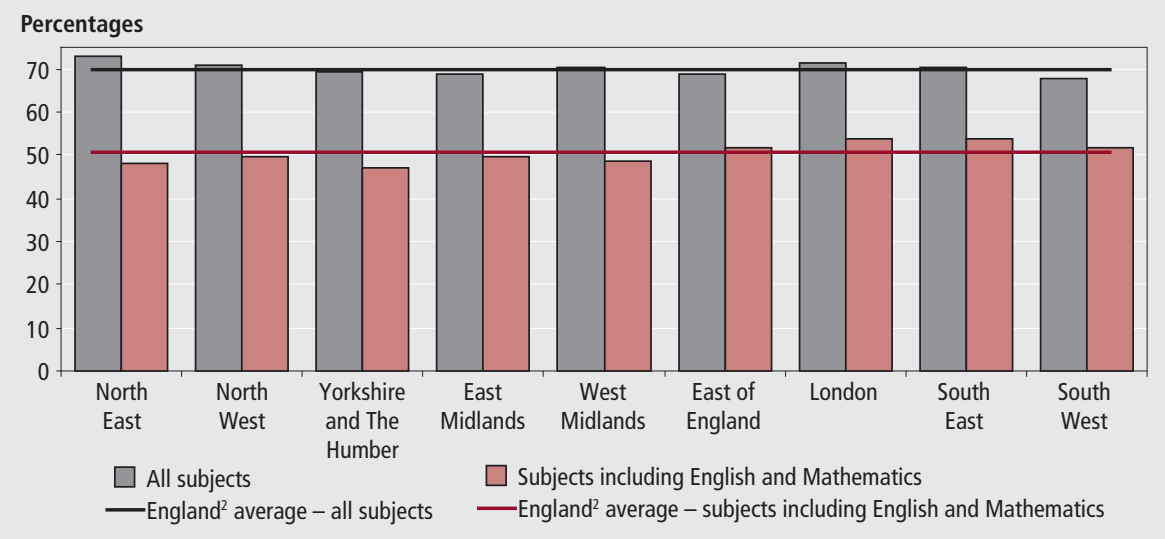

Notes:

Source: Department for Children, Schools and Families

1 Revised data, includes attempts and achievements by these pupils in previous academic years.

2 The England average includes all schools, not only local authority maintained schools.

including English and Mathematics.

Figure 11 shows the percentage of pupils achieving at least five grades $\mathrm{A}^{\star}$ to $\mathrm{C}$ at GCSE level or equivalent in any subjects, and in subjects including English and Mathematics. In 2008/2009, the England average for pupils in all schools achieving five or more grades $A^{\star}$ to $C$ in any subjects was 70.0 per cent, while it was down to 50.9 per cent if the subjects included English and Mathematics. These were increases of 4.7 and 3.3 percentage points from $2007 / 08$, respectively. Across all English regions, the percentage of pupils achieving at least five grades $A^{\star}$ to $C$ in subjects including English and Mathematics was substantially lower compared with achieving the same in any subjects. Also, regional differences were more pronounced when subjects included English and Mathematics.

In the North East the percentage of pupils achieving five or more grades $\mathrm{A}^{*}$ to $\mathrm{C}$ in any subjects was 2.8 percentage points above the England average, but the percentage dropped 2.8 points below the average when the subjects included English and Mathematics. The opposite held for the South West and the East of England, where the proportion of pupils achieving at least five grades $\mathrm{A}^{\star}$ to $\mathrm{C}$ increased above the England average if the subjects included English and Mathematics while it dropped below national average for achieving five or more grades $A^{*}$ to $C$ in any subject. London and South East were the only two regions which performed above national average on both measures.

\section{Investment}

Investment in physical capital, such as machinery, equipment and buildings, enables workers to produce more and higher quality output. Therefore, investment can have a significant positive impact on productivity. Due to quality concerns regarding the regional allocations of investment, which is recorded at the level of the enterprise and not at the local level, this article does not currently include data on investment.

Nevertheless, as Dunnell (2009) has pointed out, inflows of foreign direct investment (FDI) projects and estimated numbers of associated jobs by region can serve as a narrow indicator of investment. However, FDI does not cover all investment 
Table 7

Employment ${ }^{1}$ rates for persons of working age: by NUTS1 region

Per cent, seasonally adjusted

\begin{tabular}{|c|c|c|c|c|c|c|c|c|c|c|c|c|c|c|c|}
\hline & & $\begin{array}{r}\text { United } \\
\text { Kingdom }\end{array}$ & $\begin{array}{r}\text { North } \\
\text { East } \\
\end{array}$ & $\begin{array}{l}\text { North } \\
\text { West }\end{array}$ & $\begin{array}{r}\text { Yorkshire } \\
\text { and the } \\
\text { Humber }\end{array}$ & $\begin{array}{r}\text { East } \\
\text { Midlands }\end{array}$ & $\begin{array}{r}\text { West } \\
\text { Midlands }\end{array}$ & $\begin{array}{l}\text { East of } \\
\text { England }\end{array}$ & London & $\begin{array}{r}\text { South } \\
\text { East }\end{array}$ & $\begin{array}{r}\text { South } \\
\text { West }\end{array}$ & England & Wales & Scotland & $\begin{array}{r}\text { Northern } \\
\text { Ireland }\end{array}$ \\
\hline \multirow[t]{4}{*}{2007} & Jan-Mar & 74.3 & 70.9 & 72.4 & 72.9 & 76.0 & 72.5 & 77.4 & 70.0 & 78.2 & 78.0 & 74.3 & 71.6 & 76.6 & 70.7 \\
\hline & Apr-Jun & 74.5 & 71.6 & 72.6 & 73.3 & 76.0 & 72.7 & 77.4 & 69.9 & 78.7 & 78.1 & 74.5 & 71.9 & 77.1 & 70.7 \\
\hline & Jul-Sep & 74.6 & 72.0 & 72.4 & 73.2 & 75.7 & 73.1 & 77.3 & 70.8 & 78.9 & 78.7 & 74.7 & 71.5 & 76.4 & 70.0 \\
\hline & Oct-Dec & 74.8 & 71.5 & 72.9 & 73.7 & 75.7 & 73.2 & 78.2 & 70.3 & 79.0 & 79.3 & 75.0 & 71.7 & 76.6 & 69.6 \\
\hline \multirow[t]{4}{*}{2008} & Jan-Mar & 74.8 & 70.1 & 72.3 & 73.9 & 76.4 & 73.3 & 77.8 & 71.1 & 79.5 & 78.9 & 75.0 & 71.9 & 76.4 & 69.8 \\
\hline & Apr-Jun & 74.8 & 70.4 & 72.2 & 73.3 & 75.8 & 72.5 & 77.7 & 71.9 & 79.5 & 78.8 & 74.9 & 72.3 & 76.5 & 70.4 \\
\hline & Jul-Sep & 74.4 & 70.4 & 71.8 & 73.3 & 76.1 & 71.8 & 77.4 & 71.1 & 79.1 & 78.8 & 74.6 & 70.4 & 76.0 & 69.9 \\
\hline & Oct-Dec & 74.0 & 69.9 & 71.2 & 72.4 & 76.2 & 71.5 & 77.7 & 71.4 & 78.6 & 78.0 & 74.3 & 70.6 & 75.3 & 68.5 \\
\hline \multirow[t]{4}{*}{2009} & Jan-Mar & 73.5 & 69.6 & 71.5 & 71.7 & 75.5 & 70.2 & 77.8 & 70.2 & 78.1 & 77.7 & 73.8 & 70.3 & 74.9 & 66.8 \\
\hline & Apr-Jun & 72.7 & 67.4 & 71.0 & 71.3 & 75.3 & 70.2 & 77.1 & 68.8 & 77.3 & 76.6 & 73.0 & 69.5 & 74.0 & 65.8 \\
\hline & Jul-Sep & 72.5 & 68.2 & 70.7 & 71.2 & 74.9 & 70.0 & 77.1 & 68.6 & 77.1 & 75.7 & 72.8 & 69.0 & 73.9 & 66.3 \\
\hline & Oct-Dec & 72.4 & 69.0 & 70.4 & 70.7 & 74.6 & 70.5 & 76.2 & 68.7 & 77.0 & 75.5 & 72.6 & 68.9 & 73.5 & 67.3 \\
\hline 2010 & Jan-Mar & 72.0 & 68.8 & 70.9 & 70.5 & 73.3 & 70.6 & 75.7 & 68.5 & 76.6 & 75.0 & 72.4 & 68.6 & 72.0 & 67.9 \\
\hline
\end{tabular}

Note:

Source: Labour Force Survey, Office for National Statistics

1 Includes employees, self-employed, participants on government-supported training schemes and unpaid family workers.

Table 8

Unemployment rates for persons aged 16 and over: by NUTS1 region

Per cent, seasonally adjusted

\begin{tabular}{|c|c|c|c|c|c|c|c|c|c|c|c|c|c|c|c|}
\hline & & $\begin{array}{r}\text { United } \\
\text { Kingdom }\end{array}$ & $\begin{array}{r}\text { North } \\
\text { East }\end{array}$ & $\begin{array}{l}\text { North } \\
\text { West }\end{array}$ & $\begin{array}{l}\text { Yorkshire } \\
\text { and the } \\
\text { Humber }\end{array}$ & $\begin{array}{r}\text { East } \\
\text { Midlands }\end{array}$ & $\begin{array}{r}\text { West } \\
\text { Midlands }\end{array}$ & $\begin{array}{l}\text { East of } \\
\text { England }\end{array}$ & London & $\begin{array}{r}\text { South } \\
\text { East }\end{array}$ & $\begin{array}{c}\text { South } \\
\text { West }\end{array}$ & England & Wales & Scotland & $\begin{array}{r}\text { Northern } \\
\text { Ireland } \\
\end{array}$ \\
\hline \multirow[t]{4}{*}{2007} & Jan-Mar & 5.5 & 6.9 & 5.8 & 6.3 & 5.4 & 6.4 & 4.8 & 7.1 & 4.7 & 4.0 & 5.6 & 5.6 & 5.0 & 4.0 \\
\hline & Apr-Jun & 5.4 & 6.3 & 5.8 & 5.5 & 4.9 & 6.6 & 4.6 & 7.2 & 4.3 & 4.0 & 5.5 & 5.8 & 4.6 & 3.8 \\
\hline & Jul-Sep & 5.3 & 6.1 & 6.0 & 5.4 & 5.7 & 6.4 & 5.1 & 6.1 & 4.5 & 4.0 & 5.4 & 5.2 & 5.0 & 3.9 \\
\hline & Oct-Dec & 5.2 & 5.8 & 5.8 & 5.4 & 5.3 & 5.9 & 4.4 & 6.6 & 4.5 & 3.7 & 5.3 & 5.0 & 4.9 & 4.2 \\
\hline \multirow[t]{4}{*}{2008} & Jan-Mar & 5.2 & 6.6 & 6.0 & 5.1 & 5.3 & 6.2 & 4.5 & 6.9 & 3.9 & 3.7 & 5.3 & 5.3 & 4.7 & 4.5 \\
\hline & Apr-Jun & 5.3 & 7.4 & 6.4 & 6.0 & 5.6 & 6.1 & 4.6 & 6.7 & 4.1 & 3.8 & 5.5 & 5.2 & 4.2 & 4.1 \\
\hline & Jul-Sep & 5.9 & 8.1 & 6.8 & 6.9 & 5.9 & 6.6 & 4.8 & 7.4 & 4.5 & 4.2 & 6.0 & 6.6 & 4.8 & 4.1 \\
\hline & Oct-Dec & 6.4 & 8.4 & 7.9 & 6.7 & 6.3 & 8.0 & 5.6 & 7.3 & 5.0 & 4.8 & 6.5 & 7.0 & 5.3 & 5.3 \\
\hline \multirow[t]{4}{*}{2009} & Jan-Mar & 7.1 & 8.4 & 7.9 & 8.0 & 7.1 & 9.3 & 6.0 & 8.2 & 5.4 & 5.8 & 7.2 & 7.7 & 6.0 & 6.2 \\
\hline & Apr-Jun & 7.8 & 9.8 & 8.5 & 8.8 & 7.2 & 10.5 & 6.4 & 8.9 & 5.9 & 6.4 & 7.9 & 7.7 & 7.1 & 6.7 \\
\hline & Jul-Sep & 7.8 & 9.4 & 8.6 & 8.7 & 7.4 & 10.0 & 6.4 & 9.1 & 6.0 & 6.6 & 7.9 & 8.7 & 7.3 & 7.1 \\
\hline & Oct-Dec & 7.8 & 9.3 & 8.5 & 9.1 & 7.2 & 9.4 & 6.5 & 9.1 & 6.2 & 6.4 & 7.9 & 8.6 & 7.6 & 6.0 \\
\hline 2010 & Jan-Mar & 8.0 & 9.6 & 8.7 & 9.7 & 7.3 & 9.3 & 6.6 & 9.1 & 6.4 & 6.3 & 8.0 & 9.3 & 8.1 & 6.7 \\
\hline
\end{tabular}

Source: Labour Force Survey

in a region and there is no requirement to notify UK Trade \& Investment when undertaking FDI.

\section{The labour market}

Table 7 shows the seasonally adjusted employment rate, the number of people of working age in employment, expressed as a proportion of the population, from the Labour Force Survey (LFS).

In quarter one (January to March) of 2010, the UK employment rate was 72.0 per cent, down 1.5 percentage points from a year ago and down 0.3 percentage points from quarter four (October to December) of 2009. Regional rates varied from 76.6 per cent in the South East to 67.9 per cent in Northern Ireland.
All UK regions except the West Midlands and Northern Ireland experienced annual falls in the employment rate. The largest fall was in Scotland at 2.9 percentage points followed by the South West at 2.8 percentage points. The West Midlands and Northern Ireland increased by 0.4 and 1.1 percentage points respectively.

Table 8 shows the unemployment rate (according to the internationally-consistent International Labour Organisation definition) for persons aged 16 and over from the LFS. The UK rate in the first quarter of 2010 was 8.0 per cent, up 0.9 percentage points from a year ago and up 0.2 percentage points from the last quarter. Regionally, the rates ranged from 9.7 per cent in Yorkshire and The Humber to 6.3 per cent in the South West.
Over the year the unemployment rate rose in most regions. The West Midlands was the only exception where the rate was unchanged at 9.3 per cent. Scotland had the largest increase at 2.1 percentage points followed by Yorkshire and The Humber at 1.7 percentage points.

Table 9 shows economic inactivity rates for persons of working age from the LFS. The UK rate in the first quarter of 2010 was 21.5 per cent, up 0.2 percentage points from the previous quarter and up 0.8 percentage point on a year earlier. Across the regions, rates varied from 18.0 per cent in the South East to 27.1 per cent in Northern Ireland.

Compared with a year earlier, four regions had a decrease in the inactivity rate, 
Table 9

Economic inactivity rates for persons of working age: by NUTS1 region

Per cent, seasonally adjusted

\begin{tabular}{|c|c|c|c|c|c|c|c|c|c|c|c|c|c|c|c|}
\hline & & $\begin{array}{r}\text { United } \\
\text { Kingdom }\end{array}$ & $\begin{array}{r}\text { North } \\
\text { East }\end{array}$ & $\begin{array}{l}\text { North } \\
\text { West }\end{array}$ & $\begin{array}{l}\text { Yorkshire } \\
\text { and the } \\
\text { Humber }\end{array}$ & $\begin{array}{r}\text { East } \\
\text { Midlands }\end{array}$ & $\begin{array}{r}\text { West } \\
\text { Midlands }\end{array}$ & $\begin{array}{l}\text { East of } \\
\text { England }\end{array}$ & London & $\begin{array}{r}\text { South } \\
\text { East }\end{array}$ & $\begin{array}{r}\text { South } \\
\text { West }\end{array}$ & England & Wales & Scotland & $\begin{array}{r}\text { Northern } \\
\text { Ireland }\end{array}$ \\
\hline \multirow[t]{4}{*}{2007} & Jan-Mar & 21.2 & 23.7 & 23.0 & 22.1 & 19.6 & 22.4 & 18.5 & 24.5 & 17.8 & 18.6 & 21.1 & 24.0 & 19.3 & 26.3 \\
\hline & Apr-Jun & 21.2 & 23.5 & 22.8 & 22.4 & 20.0 & 22.0 & 18.7 & 24.6 & 17.7 & 18.5 & 21.1 & 23.5 & 19.1 & 26.5 \\
\hline & Jul-Sep & 21.1 & 23.3 & 22.9 & 22.5 & 19.6 & 21.7 & 18.4 & 24.6 & 17.2 & 18.0 & 20.9 & 24.5 & 19.5 & 27.1 \\
\hline & Oct-Dec & 21.0 & 24.0 & 22.4 & 21.9 & 19.9 & 22.0 & 18.0 & 24.5 & 17.2 & 17.5 & 20.7 & 24.4 & 19.4 & 27.2 \\
\hline \multirow[t]{4}{*}{2008} & Jan-Mar & 20.9 & 24.9 & 22.9 & 22.0 & 19.2 & 21.7 & 18.4 & 23.5 & 17.2 & 18.0 & 20.7 & 24.0 & 19.7 & 26.8 \\
\hline & Apr-Jun & 20.8 & 23.8 & 22.7 & 21.9 & 19.5 & 22.6 & 18.5 & 22.9 & 17.0 & 18.0 & 20.6 & 23.5 & 20.1 & 26.5 \\
\hline & Jul-Sep & 20.8 & 23.2 & 22.9 & 21.1 & 18.9 & 22.9 & 18.5 & 23.1 & 17.1 & 17.6 & 20.5 & 24.4 & 20.0 & 27.1 \\
\hline & Oct-Dec & 20.7 & 23.5 & 22.5 & 22.3 & 18.5 & 22.0 & 17.6 & 22.9 & 17.1 & 17.9 & 20.4 & 23.8 & 20.3 & 27.7 \\
\hline \multirow[t]{4}{*}{2009} & Jan-Mar & 20.7 & 23.8 & 22.2 & 21.8 & 18.6 & 22.3 & 17.2 & 23.4 & 17.2 & 17.3 & 20.3 & 23.6 & 20.2 & 28.7 \\
\hline & Apr-Jun & 21.0 & 25.1 & 22.2 & 21.6 & 18.6 & 21.2 & 17.5 & 24.3 & 17.7 & 18.0 & 20.6 & 24.4 & 20.2 & 29.4 \\
\hline & Jul-Sep & 21.1 & 24.5 & 22.4 & 21.7 & 18.9 & 21.9 & 17.4 & 24.3 & 17.9 & 18.8 & 20.8 & 24.1 & 20.1 & 28.6 \\
\hline & Oct-Dec & 21.3 & 23.7 & 22.8 & 21.9 & 19.4 & 21.9 & 18.4 & 24.2 & 17.7 & 19.1 & 21.0 & 24.3 & 20.2 & 28.3 \\
\hline 2010 & Jan-Mar & 21.5 & 23.8 & 22.1 & 21.5 & 20.8 & 21.9 & 18.8 & 24.5 & 18.0 & 19.8 & 21.1 & 24.0 & 21.4 & 27.1 \\
\hline
\end{tabular}

Source: Labour Force Survey

Table 10

Employee jobs: ${ }^{1}$ by NUTS1 region

Thousands, not seasonally adjusted

\begin{tabular}{|c|c|c|c|c|c|c|c|c|c|c|c|c|c|c|}
\hline & $\begin{array}{r}\text { United } \\
\text { Kingdom }\end{array}$ & $\begin{array}{r}\text { North } \\
\text { East }\end{array}$ & $\begin{array}{r}\text { North } \\
\text { West }\end{array}$ & $\begin{array}{l}\text { Yorkshire } \\
\text { and the } \\
\text { Humber }\end{array}$ & $\begin{array}{r}\text { East } \\
\text { Midlands }\end{array}$ & $\begin{array}{r}\text { West } \\
\text { Midlands }\end{array}$ & $\begin{array}{l}\text { East of } \\
\text { England }\end{array}$ & London & $\begin{array}{r}\text { South } \\
\text { East }\end{array}$ & $\begin{array}{r}\text { South } \\
\text { West }\end{array}$ & England & Wales & Scotland & $\begin{array}{r}\text { Northern } \\
\text { Ireland }\end{array}$ \\
\hline Mar 08 & 27,353 & 1,035 & 3,016 & 2,218 & 1,896 & 2,373 & 2,377 & 4,129 & 3,741 & 2,217 & 23,002 & 1,181 & 2,397 & 773 \\
\hline Mar 09 & 26,836 & 1,056 & 2,980 & 2,189 & 1,815 & 2,303 & 2,356 & 4,142 & 3,631 & 2,218 & 22,690 & 1,157 & 2,276 & 713 \\
\hline Jun 09 & 26,571 & 1,048 & 2,951 & 2,163 & 1,806 & 2,283 & 2,350 & 4,095 & 3,599 & 2,198 & 22,493 & 1,138 & 2,232 & 708 \\
\hline Sep 09 & 26,402 & 1,041 & 2,917 & 2,143 & 1,828 & 2,256 & 2,347 & 4,039 & 3,575 & 2,192 & 22,338 & 1,131 & 2,229 & 704 \\
\hline Dec 09 & 26,285 & 1,041 & 2,904 & 2,135 & 1,809 & 2,236 & 2,351 & 4,036 & 3,554 & 2,158 & 22,224 & 1,137 & 2,223 & 701 \\
\hline Mar 10 & 26,238 & 1,039 & 2,904 & 2,134 & 1,813 & 2,226 & 2,360 & 4,030 & 3,539 & 2,133 & 22,178 & 1,159 & 2,201 & 700 \\
\hline
\end{tabular}

Note:

Source: Employer surveys.

1 Employee jobs figures are of a measure of jobs rather than people. For example, if a person holds two jobs, each job will be counted in the employee jobs total. Employees jobs figures come from quarterly surveys of employers carried out by ONS and administrative sources.

Table 11

Claimant count rates: ${ }^{1}$ by NUTS1 region

Per cent, seasonally adjusted

\begin{tabular}{|c|c|c|c|c|c|c|c|c|c|c|c|c|c|c|c|}
\hline & & $\begin{array}{r}\text { United } \\
\text { Kingdom }\end{array}$ & $\begin{array}{r}\text { North } \\
\text { East }\end{array}$ & $\begin{array}{r}\text { North } \\
\text { West }\end{array}$ & $\begin{array}{l}\text { Yorkshire } \\
\text { and the } \\
\text { Humber }\end{array}$ & $\begin{array}{r}\text { East } \\
\text { Midlands }\end{array}$ & $\begin{array}{r}\text { West } \\
\text { Midlands }\end{array}$ & $\begin{array}{l}\text { East of } \\
\text { England }\end{array}$ & London & $\begin{array}{r}\text { South } \\
\text { East }\end{array}$ & $\begin{array}{c}\text { South } \\
\text { West }\end{array}$ & England & Wales & Scotland & $\begin{array}{r}\text { Northern } \\
\text { Ireland }\end{array}$ \\
\hline \multirow[t]{7}{*}{2009} & Jun & 4.8 & 7.0 & 5.5 & 5.8 & 5.0 & 6.4 & 4.1 & 4.4 & 3.4 & 3.5 & 4.8 & 5.6 & 4.6 & 5.5 \\
\hline & Jul & 4.9 & 7.1 & 5.6 & 5.9 & 5.0 & 6.5 & 4.1 & 4.5 & 3.5 & 3.5 & 4.8 & 5.6 & 4.7 & 5.7 \\
\hline & Aug & 4.9 & 7.1 & 5.7 & 6.0 & 5.1 & 6.6 & 4.2 & 4.6 & 3.5 & 3.5 & 4.9 & 5.7 & 4.7 & 5.8 \\
\hline & Sep & 5.0 & 7.1 & 5.7 & 6.0 & 5.1 & 6.7 & 4.2 & 4.6 & 3.5 & 3.5 & 4.9 & 5.7 & 4.8 & 6.0 \\
\hline & Oct & 5.0 & 7.2 & 5.7 & 6.1 & 5.2 & 6.7 & 4.2 & 4.7 & 3.6 & 3.5 & 5.0 & 5.7 & 4.8 & 6.0 \\
\hline & Nov & 5.0 & 7.1 & 5.7 & 6.0 & 5.1 & 6.6 & 4.2 & 4.7 & 3.6 & 3.5 & 4.9 & 5.7 & 4.9 & 6.0 \\
\hline & Dec & 4.9 & 7.1 & 5.6 & 6.0 & 5.1 & 6.5 & 4.1 & 4.6 & 3.5 & 3.4 & 4.9 & 5.6 & 4.9 & 6.1 \\
\hline \multirow[t]{6}{*}{2010} & Jan & 5.0 & 7.2 & 5.7 & 6.1 & 5.1 & 6.5 & 4.2 & 4.7 & 3.5 & 3.4 & 4.9 & 5.6 & 5.0 & 6.2 \\
\hline & Feb & 4.9 & 7.0 & 5.5 & 5.9 & 4.9 & 6.3 & 4.0 & 4.6 & 3.4 & 3.3 & 4.8 & 5.5 & 4.9 & 6.2 \\
\hline & Mar & 4.8 & 6.8 & 5.3 & 5.8 & 4.8 & 6.2 & 4.0 & 4.5 & 3.3 & 3.2 & 4.7 & 5.4 & 4.9 & 6.2 \\
\hline & Apr & 4.7 & 6.7 & 5.2 & 5.7 & 4.7 & 6.0 & 3.9 & 4.5 & 3.2 & 3.1 & 4.6 & 5.2 & 4.8 & 6.2 \\
\hline & May & 4.6 & 6.5 & 5.1 & 5.6 & 4.5 & 5.9 & 3.8 & 4.4 & 3.1 & 3.0 & 4.5 & 5.1 & 4.8 & 6.2 \\
\hline & Jun & 4.5 & 6.6 & 5.1 & 5.4 & 4.5 & 5.8 & 3.7 & 4.4 & 3.0 & 3.0 & 4.4 & 5.0 & 4.8 & 6.3 \\
\hline
\end{tabular}

Note:

Source: Jobcentre Plus administrative system

1. Count of claimants of Jobseeker's Allowance expressed as a percentage of the total workforce - i.e. workforce jobs plus claimants.

and thus a corresponding increase in the working-age activity rate. Northern Ireland had the largest annual fall of 1.6 percentage points. Seven regions had an increase in the economic inactivity rate over the year. The largest annual rise was in the South West at
2.5 percentage points. The North East's rate was unchanged on the year.

Table 10 shows the number of employee jobs, not seasonally adjusted, from the Employers Surveys. The number of UK employee jobs was $26,238,000$ a decrease of 598,000 over the year since March 2009. In percentage terms, this was a 2.2 per cent decrease.

There were annual decreases in ten regions. The largest percentage decrease was in the South West (down by 3.8 per cent). 
Both the East and Wales saw small increases (up by 0.2 per cent for both regions).

Table 11 shows the claimant count rate (referring to people claiming Jobseeker's Allowance benefits as a proportion of the workforce). The UK rate was 4.5 per cent in June 2010, down 0.1 percentage point since May 2010, and down 0.3 percentage points on a year earlier. This national rate masks large variations between regions and component countries of the UK. For June 2010, the North East had the highest claimant count rate in the UK at 6.6 per cent. The North East was followed by Northern Ireland (6.3 per cent) and the West Midlands (5.8 per cent). The lowest claimant count was measured in the South East and South West at 3.0 per cent.

Scotland and Northern Ireland (up by 0.2 and 0.8 percentage points respectively) are the only two regions showing a percentage increase in the claimant count rate compared with a year ago. The largest decreases were in Wales and West Midlands both down by 0.6 percentage points.

\section{Notes}

1 UK Regional Trade in Goods Statistics, Quarter 1 2010, HM Revenue and Customs at www.uktradeinfo.com/index. cfm?task=td_regstats_press

2 For a summary of all different levels of qualifications see 'Notes and definitions' at www.statistics.gov.uk/statbase/product. asp? vlnk $=836$

\section{CONTACT}

elmr@ons.gsi.gov.uk

\section{REFERENCES}

Department for Children, Schools and Families (2009) GCSE and Equivalent Examination Results in England 2008/09 (Revised) Statistical First Release at www.dcsf.gov.uk/rsgateway/DB/SFR/ s000909/index.shtml
Department for Business, Innovation and Skills (2006) Leitch Review of Skills at www.dcsf.gov.uk/furthereducation/index. $\mathrm{cfm}$ ?fuseaction $=$ content.view $\&$ CategorylD $=2$ $1 \&$ Content $\mid \mathrm{D}=37$

Department for Business, Innovation and Skills (2009) The Level of Highest Qualification Held by Adults: England 2008/09(Revised) Statistical First Release at www.dcsf.gov.uk/rsgateway/DB/SFR/ s000903/index.shtml

Dey-Chowdhury S, Penny D, Walker M and Wosnitza B (2008) 'Regional Economic Indicators February 2008 with a focus on regional productivity' Economic \& Labour Market Review 2(2), pp 48-61 and at www. statistics.gov.uk/cci/article. $a s p ? i d=1945$

Dunnell K (2009) 'National Statistician's article: measuring regional economic performance' Economic \& Labour Market Review 3(1), pp 18-30 and at www.statistics.gov.uk/cci/article. asp? $\mathrm{id}=2103$

Grierson and Allen (2008) 'Introducing the new business demography statistics' Economic \& Labour Market Review 2(12), pp 53-5 and at

www.statistics.gov.uk/cci/article. asp? $\mathrm{id}=2096$

HM Revenue \& Customs (2009) UK Regional Trade Statistics Quarter 32009 at www.uktradeinfo.com/index.cfm?task $=$ td_ regstats_press

HM Treasury (2004) Productivity in the UK 5: Benchmarking UK Productivity Performance. A Consultation on Productivity Indicators at www.hm-treasury.gov.uk/consult_ productivity_indicators_index.htm

Office for National Statistics Annual Survey of Hours and Earnings at

www.statistics.gov.uk/statbase/product. asp?vlnk=13101

Office for National Statistics Business Demography at www.statistics.gov.uk/statbase/product. asp?vInk=15186
Office for National Statistics Business Expenditure on Research \& Development by Government Office Region at www.statistics.gov.uk/statbase/tsdataset. asp?vlnk= 572

Office for National Statistics Regional Household Income May 2008 Statistical First Release at www.statistics.gov.uk/statbase/product. asp?vInk=14651

Office for National Statistics Regional, subregional and gross value added, December 2009 at

www.statistics.gov.uk/statbase/Product. asp? vInk=14650

Office for National Statistics Regional Trends 37: Notes and Definitions at www.statistics.gov.uk/statbase/product. asp? vlnk $=836$

Office for National Statistics (2007) The ONS Productivity Handbook: A Statistical Overview and Guide at www.ons.gov.uk/about-statistics/userguidance/productivity-handbook/index.html

Organisation for Economic Co-operation and Development (2002) Frascati Manual: Proposed Standard Practice for Surveys on Research and Experimental Development

Organisation for Economic Co-operation and Development (2003) 'Identifying the Determinants of Regional Performances' Working Party on Territorial Indicators 